\title{
ЛІКУВАННЯ ЗАГОСТРЕНЬ ІНФЕКЦЇ̈ СЕЧОВИВІДНИХ ШЛЯХІВ В АМБУЛАТОРНИХ УМОВАХ
}

Кафедра сімейної медицини та амбулаторно-поліклінічної допомоги (зав. - проф. Л. Ф. Матюха) Національної медичної академії післядипломної освіти ім. Л. П. Шупика <titta3001@gmail.com>

\begin{abstract}
Вивчали ефективність застосування перорального антимікробного препарату Флапрокс та оцінювали динаміку клініко-лабораторних показників порівняно з терапією нітрофуранами у хворих із загостренням хронічної інфекиії сечовивідних шляхів в амбулаторних умовах. Досліджено результати терапії 40 пацієнтів із загостренням хронічного пієлонефриту у вічі $(39,8 \pm 8$,9) року. Хворі I групи (26 осіб) отримували препарат флапрокс по 500 мг 2 рази на добу протягом 10 днів, II групи (14 осіб) препарат нітрофурану 0,1 г 4 раза на добу 10 днів. Регресування клінічних проявів інфекиії сечовивідних иляхів в процесі дослідження відмічено в обох групах. В I групі динаміка зменшення симптомів загальної інтоксикації та нормалізації місиевих симптомів $і$ запальних змін в крові та сечі була більш вираженою з 5-го дня лікування $i$ зберігалася протягом всього курсу терапії. Застосування препарату флапрокс протягом 10 днів дозволяє достовірно зменшити або усунути прояви дизурії, інфікування сечових шляхів (бактеріурія), запального процесу (лейкоцитурія) без негативних змін у біохімічному аналізі крові.
\end{abstract}

Ключові слова: інфекції сечовивідних шляхів; пієлонефрит; флапрокс; кишкова паличка; біоплівки; лейкоцитурія; бактеріурія.

Актуальність теми. Інфекції сечовивідних шляхів (ICШ) є найпоширенішим захворюванням серед різних вікових категорій. Вони посідають перше місце за частотою серед всіх нефрологічних захворювань та одне з провідних місць серед інфекційної патології людини. Персистенція цих захворювань протягом тривалого часу призводить до зниження функції нирок за рахунок розвитку тубулоінтерстиціальних змін, порушення уродинаміки та розвитку хронічної хвороби нирок, що обумовлює не тільки медичне, але й економічне значення даної проблеми. ВООЗ вважає пієлонефрит проблемою соціального значення, оскільки захворювання частіше розвивається в осіб працездатного віку і нерідко стає причиною інвалідизації хворих.

Епідеміологія Епідеміологія інфекції сечовивідних шляхів різноманітна. Структура мікрофлори залежить від нозології захворювання, його перебігу чинників, що провокують запальний процес.

Спектр етіологічних агентів при інфекції нижніх і верхних сечовивідних шляхів досить однаковий. У ньому переважають здебільшого представники сімейства Enterobacteriaceae, а серед них кишкова паличка (Escherichia coli), частка якої, за даними різних авторів, становить від 40 до $90 \%$. Висока частка серед збудників Staphylococcus (S.) saprophyticus (5-10\%), також виділяють й інших представників Enterobacteriaceae, зокрема Proteus (P.) mirabilis, Klebsiella $(K$.$) pneumoniae, енте-$ рококи, грампозитивні організми, такі як стрептококи групи В i D, що становлять близько $1-2 \%$.

Таким чином, основним збудником ICШ вважають Escherichia coli. Даний мікроорганізм широко представлений в нормофлорі (до $10^{8} \mathrm{KУО/Г),} \mathrm{в} \mathrm{нормі} \mathrm{сприяє}$ стимуляції імунореактивності організму за рахунок постійного подразнення системи локального імунітету $[9,17]$. Досліждена здатність деяких видів синтезувати вітаміни групи В і К, антибактеріальні речовини (мікроцин і коліцин), коротколанцюгові жирні кислоти. В умовах зниження чисельності популяції й ослаблення протекторних властивостей облігатних сахаролітичних мікроорганізмів концентрація E. coli може різко збільшуватися, реалізуючи патогенні властивості $[3,9]$. 
E. coli має широкий спектр ферментів, гемопротеїнів (цитохроми і каталази), які можуть активно розвиватися і отримувати енергію як в аеробних, так і в анаеробних умовах [3]. Саме ці фактори пояснюють унікальний адаптивний механізм даних мікроорганізмів та їх здатність швидко реагувати на зміни умов життя.

Уропатогенні штами E. coli мають ряд особливостей, які підвищують їхню адаптацію до умов сечовивідного тракту, і піогенну агресивність (здатність індукувати гнійне запалення) [4]. Вони також високо споріднені до уротелію - адгезію до клітин епітелію внаслідок фімбрій і ворсин, що перешкоджає розвитку імунної відповіді пацієнта [4]. В дослідженнях було показано, що бактерії здатні проникати в уротелій ниркових мисок і ниркові сосочки та адгезувати на уроепітелії перш ніж проникнути у тканину нирки $[11,31]$. При перевищенні допустимої концентрації клітин E. coli реалізується здатність цих мікроорганізмів мігрувати в мезентеріальні лімфатичні вузли і в кров з подальшим розвитком генералізованих інфекційних процесів.

У відповідь на проникнення уропатогенних бактерій і їх адгезію до епітеліальних клітин макроорганізму включається універсальний захисний механізм апоптоз ушкоджених клітин, їх злущування 3 подальшим видаленням при сечовипусканні, що перешкоджає розвитку запальних захворювань в нижніх сечових шляхах. Бактерії, що встигли проникнути в більш глибокі шари і знаходяться в біоплівках, уникають процесу апоптозу.

Велике значення у формуванні інфекційних процесів надають концепції бактеріальних біоплівок. За даними досліджень, близько 65 \% інфекцій обумовлено саме біоплівками, які розглядають як структурне поєднання мікроорганізмів, інкапсульованих в саморозвиненому полімерному матриксі, адгезоване до біотичної або абіотичної поверхні $[11,21]$.

Формування біоплівок відбувається за кількома етапами, протягом яких мікроорганізми активно змінюють поверхневі властивості слизових оболонок або сторонніх тіл та сприяють адгезії планктонних (плаваючих) бактеріальних клітин. Розвинена біоплівка складається з групи мікроорганізмів, відокремлених інтерстиціальними проміжками, заповненими навколишньою рідиною. Основною структурною одиницею біоплівки є мікроколонія, яка залежно від виду мікроорганізмів, що іiі формують, містить 10-25 \% мікробних клітин та 75-90 \% екзополісахаридного матриксу, а також водні канали, через які надходять додаткові поживні речовини і кисень, необхідні для росту клітин $[11,24]$.

Особливості Хронічні інфекції принципово відрізняються від гострих інфекційного фактора формуванням біоплівок. Фагоцити макроорганізму не при пієлонефриті здатні поглинати біоплівки, на відміну від окремих бактеріальних клітин $[14,36]$. Штами, виділені від хворих на хронічний пієлонефрит, у разі можливості формування біоплівок значно перевершували штами, виділені від хворих на гострий пієлонефрит. Інтенсивне утворення біоплівок клінічними ізолятами $E$. coli, $P$. aeruginosa, $K$. pneumoniae, S. aureus $\epsilon$ важливим фактором хронізації інфекцій сечовидільного тракту [7].

Відмічено також більшу здатність формування біоплівок для мікроорганізмів збудників пієлонефриту, що перебігає на фоні сечокам'яної хвороби [7].

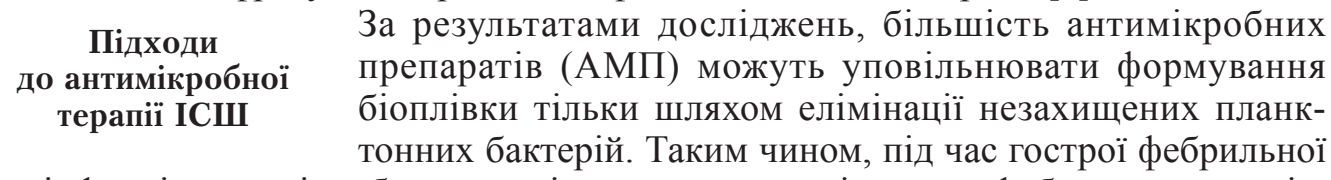
фази інфекції антимікробної терапії достатньо, оскільки за фебрильну реакцію відповідальні саме планктонні бактерії. Однак бактерії в біоплівці є факторами ризику рецидиву запального процесу, що зумовлено вивільненням планктонних мікроорганізмів 3 поверхневого шару зрілої біоплівки, їхнім поширенням над поверхнею, розвитком бактеріурії, а в подальшому бактеріємії, ендотоксинемії та 
інших гострих інфекційно-запальних ускладнень, в тому числі синдрому системної запальної реакції й уросепсису.

Слід зазначити, що АМП, ефективні проти планктонних бактерій, часто не виявляють необхідної антимікробної дії на бактеріальні біоплівки. Це, з одного боку, пов'язано з тим, що вибір АМП грунтується на чутливості бактеріальної культури, отриманої з планктонних бактерій. Разом 3 тим, планктонні бактерії відрізняються від бактерій в біоплівці поведінкою і фенотиповими формами. 3 іншого боку, неефективність антимікробної терапії в лікуванні інфекції, зумовленої бактеріальними біоплівками, можна пояснити такими факторами $[11,35]$ :

- $\quad$ непроникненням АМП на всю глибину біоплівки через бар'єрну функцію глікокаліксу, що покриває іiї зовні;

- уповільненням або припиненням пенетрації АМП в глибокі шари мікробної біоплівки внаслідок звуження водних канальців у біоплівці;

- виведенням АМП назовні матриксом біоплівки (ефлюкс, або зовнішня резистентність);

- дезактивацією (нейтралізація) позитивно зарядженого антибіотика негативно зарядженим полімером матриксу;

- переходом бактерій в стан своєрідного анабіозу і затримки реплікації, тобто мікроорганізми в біоплівці ростуть повільніше, тому вони більш стійкі до антимікробних препаратів;

- $\quad$ протеїнами, що зв'язують антимікробні препарати, недостатньо експресуються у бактерії в біоплівці;

- активацією в біоплівках бактерій багатьма генами, якими змінюють клітинну оболонку, молекулярні мішені і чутливість до антимікробних препаратів (внутрішня резистентність);

- здатністю бактерій синтезувати ферменти, що безпосередньо руйнують антибіотик.

Таким чином, бактерії в біоплівці можуть виживати за наявності антимікробних препаратів в концентрації, вищій в 1000-1500 разів за необхідну для ерадикації планктонних клітин того самого виду бактерій (клітини-персистери) $[11,28]$.

Для лікування інфекції, викликаної біоплівкою, слід застосовувати АМП, які добре проникають через глікокалікс і мають високу бактерицидну активність щодо повільно зростаючих бактерій $[11,34]$. Слід зазначити, що АМП більш ефективні проти біоплівок безпосередньо СВШ порівняно з біоплівками на катетерах [11, 30]. Це може бути обумовлено синергічною дією антибактеріальних препаратів і факторів захисту макроорганізму [11, 29].

Можливість антимікробних препаратів проникати в біоплівку значною мірою різниться і залежить як від типу АМП, так і від віку біоплівки. Аміноглікозиди і бета-лактами здатні перешкоджати формуванню «молодих» біоплівок, тоді як фторхінолони завдяки значній проникаючій здатності, ефективні щодо «молодих» і «старих» біоплівок. Більше того, концентрація фторхінолонів тривалий час зберігається в даних структурах і їх виявляють у біоплівках протягом 1-2 тиж після закінчення курсу антибактеріальної терапії [11, 32, 33].

Розвиток резистентності до АМП першої лінії - започатковані широкомасштабні дослідження 3 визначення чутливості мікрорганізмів: АРМІДА (20002001 pp.), AREST (2008-2009 pp.), ДАРМIC (2011 р.). За результатами досліджень, зроблено акценти на застосуванні АМП в терапії ІСШ залежно від рівня ураження сечовивідної системи, ускладнень процесу та чутливості мікрофлори. При неускладненому циститі перевагу в застосуванні надають нітрофуранам, цефалоспоринам та триметоприму.

Слід зауважити, що неускладнений цистит у чоловіків без залучення до процесу передміхурової залози зустрічається рідко, тому для пацієнтів із симптомами 
ІСШ необхідне лікування АМП, що проникають у тканину передміхурової залози. Відповідно рекомендують тривалість лікування не менше семи днів, переважно iз застосуванням триметоприму сульфаметоксазолу або фторхінолону з урахуванням результатів тесту на чутливість мікрофлори (табл. 1).

Таблиия 1. Рекомендовані схеми емпіричної пероральної антимікробної терапії при неускладненому післонефриті (2018) [20]

\begin{tabular}{l|l|c|l}
\hline \multicolumn{1}{c}{$\begin{array}{c}\text { Антимікробний } \\
\text { препарат }\end{array}$} & \multicolumn{1}{c}{ Добова доза } & $\begin{array}{c}\text { Тривалість } \\
\text { терапії, дні }\end{array}$ & \multicolumn{1}{c}{ Примітка } \\
\hline \hline Ципрофлоксацин & $\begin{array}{l}500-750 \text { мг двічі } \\
\text { на добу }\end{array}$ & 7 & $\begin{array}{l}\text { Стійкість до фторхінолону повинна } \\
\text { бути менше } 10 \%\end{array}$ \\
$\begin{array}{l}\text { Левофлоксацин } \\
\text { Триметоприм } \\
\text { сульфаметоксазол }\end{array}$ & $\begin{array}{l}160 / 800 \text { мг двічі } \\
\text { на добу }\end{array}$ & 14 & $\begin{array}{l}\text { Якщо такі агенти використовують } \\
\text { Цепірично, слід вводити первинну } \\
\text { Цефподоксим }\end{array}$ \\
$\begin{array}{l}\text { 200 мг двічі } \\
\text { на добу }\end{array}$ & 10 & $\begin{array}{l}\text { внутрішньовенну дозу тривалої } \\
\text { парентеральної антимікробної } \\
\text { Церапії (наприклад, цефтріаксон) }\end{array}$ \\
\hline
\end{tabular}

Нітрофурани (нітрофурантоїн, фуразидин), як і інші уроантисептики, не рекомендовано призначати при пієлонефриті, оскільки вони не сприяють створенню необхідної концентрації в тканині нирок [15]. Тому перевагу при антимікробній терапії пієлонефриту надають препаратам групи цефалоспоринів і фторхінолонів, високоефективних при терапії ІСШ різної локалізації. Цефалоспорини частіше рекомендують для дітей і вагітних, фторхінолони - для дорослих.

Слід зауважити, що за класифікацією, прийнятою EAU та внесеною до Urological Infections Guidelines (2017), до ускладнених інфекцій сечовивідних шляхів належать всі випадки захворювання у пацієнтів з ризиками ускладненого перебігу ІСШ, тобто чоловіки, пацієнти з анатомічними або функціональними порушеннями сечового тракту, постійними сечовими катетерами, захворюваннями нирок i/або іншими супутніми імунодефіцитними станами (наприклад, діабет) тощо.

Як препарати першої лінії при лікуванні ускладнених ICШ також розглядають фторхінолони, які застосовують при асоційованих із структурними порушеннями органів сечостатевого апарату станах, супутніх захворюваннях та при ІСШ з обтяженим перебігом $[19,20,26]$. Такий підхід відповідає рекомендаціям Європейської асоціації урологів (EAU 2015, 2017, 2018) та залишається актуальним [20].

Серед фторхінолонів провідне місце в терапії ІСШ на амбулаторному етапі посідає ципрофлоксацин. Широке застосування препаратів ципрофлоксацину обумовлено спектром дії, високою біодоступністю при прийомі per os, здатністю препарату проникати практично в усі біологічні середовища (це надає перевагу фторхінолонам при таких ІСШ, як пієлонефрит, а також при епідидиміті і простатиті, перед препаратами інших груп, які не сприяють створенню необхідної концентрації в тканинах органів-мішеней), високою ефективністю щодо практично всіх груп мікроорганізмів - збудників ІСШ при порівняно низьких мінімальних пригнічувальних концентраціях.

Механізм дії ципрофлоксацину полягає в інгібуванні ферментів ДНК-гірази, топоізомераз II і IV, що призводить до порушення реплікації бактеріальної ДНК, забезпечуючи таким чином бактерицидну дію препарату. Досліджено додаткові механізми впливу фторхінолонів, зокрема ципрофлоксацину, при запальних процесах. Фторхінолони з циклопропілфрагментом в положенні N1 структури ядра хінолону (ципрофлоксацин, моксифлоксацин, грепафлоксацин, спарфлоксацин) стимулюють синтез IL-2 і $\gamma \mathrm{IFN}$, знижують продукування прозапальних цитокінів IL-1 i TNF $\alpha$. Імуномодулююча дія цих фторхінолонів обумовлена впливом на внутрішньоклітинні циклічні АМФ і фосфодіестерази, на фактори транскрипції, такі 
як NF-каппа $\beta$ тощо. Слід зазначити, що фторхінолони мають імуномодулюючу активність, зокрема при латентних або хронічних інфекціях [23]. Таким чином вони запобігають розвитку хронізації перебігу запального процесу. Отже, ципрофлоксацин забезпечує комплексну дію в сечовивідних шляхах, оскільки не тільки сприяє елімінації збудників, а й регулює місцеві захисні реакції тканин.

Мета дослідження - вивчити ефективність застосування перорального антимікробного препарату Флапрокс виробництва «Біофарма» (Туреччина), що містить в одній таблетці 500 мг ципрофлоксацину, та динаміки клініко-лабораторних показників порівняно з традиційною терапією нітрофуранами у пацієнтів із загостренням хронічної інфекції сечовивідних шляхів в амбулаторних умовах.

Матеріали і методи. Досліджено й одночасно проконтрольовано 40 пацієнтів (16 чоловіків, 24 жінки) із загостренням хронічного пієлонефриту. До I (основної) групи ввійшло 26 хворих, до II (контрольної) групи - 14 хворих. Середній вік пацієнтів - $(39,8 \pm 8,9)$ року. Дослідження проводили на базі амбулаторії селища Хотів Київської області.

У всіх хворих загострення хронічного пієлонефриту підтверджено клініколабораторними показниками, морфологічно - показники сечі відповідали клінічним даним і характеризувалися маркерами активного запального процесу.

Пацієнти I групи (26 хворих) отримували препарат Флапрокс по 500 мг 2 рази на добу протягом 10 днів, пацієнти II групи - стандартну терапію з використанням нітрофуранів (фурагін) 0,1 г 4 рази на добу 10 днів. Усім пацієнтам рекомендували дотримувати дієти, водного режиму, призначали жарознижувальні препарати в перші 2 дні лікування, які в подальшому відміняли. На етапі лікування I і II групи були порівнянні за діагнозом, віком, статтю.

На 5-й день лікування та на 10-й день закінчення антибактеріальної терапії проводили контроль за станом пацієнтів. У хворих оцінювали клінічні прояви загострення сечових шляхів і симптомів інтоксикації організму. Серед клінічних ознак звертали увагу на загальні симптоми інтоксикації (підвищення температури тіла, головний біль, біль у м'язах, пітливість, слабість) та місцеві прояви у вигляді дизурії, болю у попереку, болем при пальпації в ділянці нирок, позитивного симптому Пастернацького. Основні клінічні симптоми рєєстрували перед початком та на 5-й і 10-й день лікування. Інформацію про стан хворих і отримані результати терапії заносили в індивідуальні реєстраційні картки.

В динаміці пацієнтам виконували лабораторні та інструментальні дослідження. Кров і сечу досліджували до призначення терапії, на 5-й день лікування та відразу після його закінчення. Загальний аналіз сечі і аналіз сечі за Нечипоренком проводили до прийому антибактеріальних препаратів, на 5-й день лікування i після його закінчення. В крові ознаки загострення запального процесу оцінювали за вираженістю показників - лейкоцитоз, зміщення формули вліво, рівень ШОЕ; при проведенні макроскопічного дослідження сечі і мікроскопічного дослідження сечового осаду - за лейкоцитурією, ознаками ураження епітелію сечових шляхів, бактеріурією.

Ультразвукове дослідження проводили всім хворим перед початком антибактеріальної терапії і після неї, під час якого визначали стан кортико-медулярного шару. Супутні захворювання у пацієнтів обох груп були у стані ремісії і компенсації.

Статистичну обробку отриманих результатів дослідження проводили за програмою Excel.

Критерії виключення: хронічна ниркова недостатність, об'ємні процеси, вагітність, наявність сечового катетера, гострий пієлонефрит, гострий цистит, анемія.

Критерії ефективності: зменшення клінічних проявів (дизурія, біль у попереку, зниження температури тіла, больовий синдром, біль у м’язах, пітливість, 
слабість), лабораторних ознак загострення запального процесу (лейкоцитурія, бактеріурія), ультразвукових змін (покращання стану кортико-медулярного шару).

Результати та їх обговорення. У пацієнтів I групи швидше, ніж II групи, зменшувалися клінічні прояви, нормалізувалися лабораторні та інструментальні показники. Симптоми інтоксикації, головний біль зникали на 3-й день. Дизуричні прояви зменшувалися на 5-й день у 69 \% пацієнтів в I групі і у 57 \% пацієнтів II групи. Симптом Пастернацького ставав негативним на 5-й день, чутливість нирок при пальпації на 5-й день зберігалася у 59 \% I групи і у 68 \% у II групі.

При лабораторному дослідженні виявлено зникнення запальних змін у сечі. Так, лейкоцитурія поступово зменшувалася в обох групах, проте в I групі позитивна динаміка відбувалася швидше і кількісні показники лейкоцитів у сечі на 5-й день були нижчими порівняно з II групою; лейкоцити в пробі сечі за Нечипоренком знизилися до 10-20 в полі зору $\pm 3-4(\mathrm{P}<0,01)$ в I групі у $100 \%$ пацієнтів на 10-й день, в II групі - у 89 \%. Зникнення бактеріурії спостерігалося в обох групах однаково на 10-й день.

\section{Таблиия 2. Загальні симптоми інтоксикації}

\begin{tabular}{|c|c|c|c|c|c|c|}
\hline \multirow{3}{*}{ Симптом інтоксикації } & \multicolumn{6}{|c|}{ Група } \\
\hline & \multicolumn{2}{|c|}{ до лікування } & \multicolumn{2}{|c|}{ 5-й день лікування } & \multicolumn{2}{|c|}{ 10-й день лікування } \\
\hline & I & II & I & II & I & II \\
\hline Температура тіла & Підвищена & Підвищена & - & $\stackrel{+}{+} \%$ & - & - \\
\hline Головний біль & +++ & +++ & + & ++ & - & - \\
\hline Біль у м'язах & +++ & +++ & + & ++ & - & - \\
\hline Пітливість & +++ & +++ & + & ++ & - & - \\
\hline Слабість & +++ & +++ & + & +++ & - & + \\
\hline
\end{tabular}

Таблиця 3. Місцеві симптоми інтоксикації, \%

\begin{tabular}{|c|c|c|c|c|c|c|}
\hline \multirow{3}{*}{ Місцеві клінічні прояви } & \multicolumn{6}{|c|}{ Група } \\
\hline & \multicolumn{2}{|c|}{ до лікування } & \multicolumn{2}{|c|}{ 5-й день лікування } & \multicolumn{2}{|c|}{ 10-й день лікування } \\
\hline & I & II & I & II & I & II \\
\hline Дизурія & 100 & 100 & 31 & 43 & 0 & 1 \\
\hline Біль у попереку & 100 & 100 & 48 & 56 & 0 & 0 \\
\hline $\begin{array}{l}\text { Болючість при пальпації } \\
\text { в ділянці нирок }\end{array}$ & 100 & 100 & 59 & 68 & 0 & 0 \\
\hline $\begin{array}{l}\text { Симптом Пастерна- } \\
\text { цького }\end{array}$ & $\begin{array}{l}\text { Позитив- } \\
\text { ний }\end{array}$ & $\begin{array}{c}\text { Позитив- } \\
\text { ний }\end{array}$ & $\begin{array}{l}\text { Негатив- } \\
\text { ний }\end{array}$ & $\begin{array}{c}\text { Позитив- } \\
\text { ний } \\
62 \\
\end{array}$ & $\begin{array}{c}\text { Негатив- } \\
\text { ний }\end{array}$ & $\begin{array}{c}\text { Негатив- } \\
\text { ний }\end{array}$ \\
\hline
\end{tabular}

Таблиия 4. Лабораторні показники

\begin{tabular}{|c|c|c|c|c|c|c|}
\hline \multirow{3}{*}{ Показник } & \multicolumn{6}{|c|}{ Група } \\
\hline & \multicolumn{2}{|c|}{ до лікування } & \multicolumn{2}{|c|}{ 5-й день лікування } & \multicolumn{2}{|c|}{ 10-й день лікування } \\
\hline & I & II & I & II & I & II \\
\hline & \multicolumn{6}{|c|}{ Сечовий осад, \% } \\
\hline \multicolumn{7}{|l|}{ Лейкоцитурія: } \\
\hline загальний аналіз сечі & 100 & 100 & 18 & 23 & 0 & 0 \\
\hline аналіз сечі за Нечипоренком & 100 & 100 & 26 & 34 & 0 & 11 \\
\hline Бактеріурія & ++ & ++ & - & + & - & - \\
\hline Епітелій сечових шляхів & +++ & +++ & + & $\begin{array}{c}++ \\
17\end{array}$ & - & $\begin{array}{l}+ \\
3\end{array}$ \\
\hline
\end{tabular}


Закінчення табл. 4

\begin{tabular}{|c|c|c|c|c|c|c|}
\hline \multirow{3}{*}{ Показник } & \multicolumn{6}{|c|}{ Група } \\
\hline & \multicolumn{2}{|c|}{ до лікування } & \multicolumn{2}{|c|}{ 5-й день лікування } & \multicolumn{2}{|c|}{ 10-й день лікування } \\
\hline & $\mathrm{I}$ & II & $\mathrm{I}$ & II & $\mathrm{I}$ & II \\
\hline & \multicolumn{6}{|c|}{ Кров } \\
\hline Лейкоцитоз & +++ & +++ & + & ++ & - & - \\
\hline \multirow[t]{2}{*}{ ШOE } & ++ & ++ & ++ & +++ & + & ++ \\
\hline & \multicolumn{6}{|c|}{ УЗД } \\
\hline $\begin{array}{l}\text { Ультразвукова візуалізація нирок } \\
\text { (зміни кортикомедулярного } \\
\text { шару) }\end{array}$ & +++ & +++ & + & ++ & - & + \\
\hline
\end{tabular}

Застосування препарату Флапрокс при лікуванні загострень хронічної інфекції сечовивідних шляхів дало можливість швидше, ніж в II групі, досягти бажаного терапевтичного ефекту, що підтверджено результатами клініко-лабораторних показників.

Висновки. Розглянуто питання етіології та фактори, що впливають на хронізацію ІСШ, підходи та рекомендації з терапії даних захворювань, в тому числі 3 урахуванням сучасних знань про поєднання мікроорганізмів. Досліджено можливості оптимізації антимікробної терапії лікарями загальної практики - сімейними лікарями при веденні пацієнтів з ІСШ в амбулаторних умовах. Зазначено, що на сучасному етапі призначення АМП при пієлонефриті необхідно проводити не лише 3 урахуванням збудників ІСШ та їхню чутливість до препаратів in vitro, але й здатність до формування біоплівок. Обгрунтовано клінічну ефективність препарату Флапрокс завдяки впливу на систему сечовиділення, бактерицидну дію на основні збудники ІСШ на різних етапах контамінації сечових шляхів, в тому числі при бактеріальних біоплівках, протизапальну дію та імуномодулюючу активність ципрофлоксацину.

Показано ефективність терапії ІСШ препаратом Флапрокс порівняно із застосуванням нітрофуранів та досягнення позитивної динаміки клінічних і лабораторних показників за більш короткий термін. На фоні прийому препарату Флапрокс швидше змінювалися загальні (температура тіла, пітливість, слабість) і місцеві (дизурія, локальний біль) клінічні прояви, лабораторні (лейкоцитурія, бактеріурія, епітеліальні клітини) та інструментальні (стан кортико-медулярного шару) показники, більш виражену тенденцію спостерігали вже з 5-го дня лікування, яка зберігалася протягом всього курсу терапії. Це дозволяє рекомендувати препарат Флапрокс як антимікробну терапію при загостренні хронічної інфекції сечовивідних шляхів в умовах амбулаторії.

\section{Спи сок літератури}

1. Берестенко С. В. Эффективность антисептика Декасан в комплексном лечении больных с обострением хронического цистита // Здоровье мужчины. - 2012. № 2. - C. 22-28.

2. Ермоленко В. М., Филатова Н. Н., Малкоч $A . B$. Инфекция мочевых путей и ее лечение в возрастном аспекте // Лечащий врач. - 2012. - № 8. - С. 8-11.

3. Жабченко И.А. Уропатогенные штаммы Escherichia coli: особенности функционирования, факторы вирулентности, значение в клинической практике // Тавриче-
1. Berestenko $S$. $V$. Ehffektivnost' antiseptika Dekasan v kompleksnom lechenii bol'nyh s obostreniem hronicheskogo cistita // Zdorov'e muzhchiny. - 2012. - № 2. S. 22-28.

2. Ermolenko V. M., Filatova N. N., Malkoch $A$. $V$. Infekciya mochevyh putej i ee lechenie v vozrastnom aspekte // Lechashchij vrach. - 2012. - № 8. - S. 8-11.

3. Zhabchenko I. A. Uropatogennye shtammy Escherichia coli: osobennosti funkcionirovaniya, faktory virulentnosti, znachenie v klinicheskoj praktike // Tavricheskij med.- 
ский мед.-биол.вестн. - 2013. - Т. 16, № 2, Ч. 2 (62). - С. 201-206.

4. Зайцеев $A$. В. Особенности лечения и профилактики неосложнённой инфекции нижних мочевыводящих путей у женщин. Лекции для врачей // Эффективная фармакотерапия. - 2015. - № 4. - С. 22-30.

5. Іванов Д. Д., Кушніренко С. В. Інфекції сечових шляхів у практиці сімейного лікаря // Семейная медицина. - 2015. - № 2. С. 46-50.

6. Іванов Д. Д. Інфекції сечових шляхів: лікування пієлонефриту // Почки. - 2013. № 3. - C. 11-20.

7. Лагун Л. В., Атанасова Ю. В., Тапальский Д. В. Формирование микробных биоплёнок у возбудителей острого и хронического пиелонефрита // Журн. микробиологии, эпидемиологии и иммунобиологии. - 2013. - № 3. - С. 18-23.

8. Маянский $A$. Н. Цитокины и медиаторные функции уроэпителия в воспалительных реакциях мочевыводящей системы // Цитокины и воспаление. - 2003. - № 4. C. 1-8.

9. Медична мікробіологія, вірусологія, імунологія / За ред. акад. В. П. Широбокова. - Вид. 2-ге. - Вінниця: Нова книга, 2011. -952 c.

10. Палагин И. С., Сухорукова М. В., Дехнич $A$. В. и др. Современное состояние антибиотикорезистентности возбудителей внебольничных инфекций мочевых путей в России: результаты исследования ДАРМИС (2010-2011) // Клин. микробиол. антимикроб. химиотер. - 2012. T. 14, № 4. - С. 280-320.

11. Перепанова Т. С. Значение инфекций, обусловленных образованием биоплёнок, в урологической практике // Эффективная фармакотерапия. - 2013. - № 44. - С. 1827.

12. Перепанова Т. С., Волкова Е. М. К вопросу патогенеза рецидивирующей инфекции нижних мочевыводящих путей // Эксперим. и клинич. урология. - 2015. № 3. - C. 100-105.

13. Перепанова Т. С., Козлов Р. С., Дехнич $A$. B. и др. Эмпирический выбор антимикробных препаратов при неосложнённой инфекции нижних мочевых путей: исследование резистентности возбудителей ДАРМИС // Там же. - 2012. - №2. С. 78-83.

14. Петухова И. Н. Роль биоплёнок в хронизации инфекций мочевых путей // Урология сегодня. - 2013. - № 2. - С. 14-15.

15. Практическое пособие по антиинфекционной химиотерапии / Под ред. Л. С. Стра- biol.vestn. - 2013. - T. 16, № 2, Ch. 2 (62). S. 201-206.

4. Zajcev A. V. Osobennosti lecheniya i profilaktiki neoslozhnennoj infekcii nizhnih mochevyvodyashchih putej u zhenshchin. Lekcii dlya vrachej // EHffektivnaya farmakoterapiya. -2015 . - № 4 . - S. 22-30.

5. Ivanov D. D., Kushnirenko $S$. V. Infekciï sechovih shlyahiv u praktici simejnogo likarya // Semejnaya medicina. - 2015. № 2. - S. 46-50.

6. Ivanov D. D. Infekciï sechovih shlyahiv: likuvannya piєlonefritu // Pochki. - 2013. № 3. - S. 11-20.

7. Lagun L. V., Atanasova Yu. V., Tapal'skij D. V. Formirovanie mikrobnyh bioplenok u vozbuditelej ostrogo i hronicheskogo pielonefrita // ZHurn. mikrobiologii, ehpidemiologii i immunobiologii. - 2013. - № 3. S. 18-23.

8. MayanskijA. N. Citokiny i mediatornye funkcii uroehpiteliya v vospalitel'nyh reakciyah mochevyvodyashchej sistemy // Citokiny i vospalenie. - 2003. - № 4. - S. 1-8.

9. Medichna mikrobiologiya, virusologiya, imunologiya / Za red. akad. V. P. SHirobokova. - Vid. 2-e. - Vinnicya: Nova kniga, 2011. - $952 \mathrm{~s}$.

10. Palagin I. S., Suhorukova M. V., Dekhnich A. V. i dr. Sovremennoe sostoyanie antibiotikorezistentnosti vozbuditelej vnebol'nichnyh infekcij mochevyh putej v Rossii: rezul'taty issledovaniya DARMIS (20102011) // Klin. mikrobiol. antimikrob. himioter. - 2012. - T. 14, № 4. - S. 280-320.

11. Perepanova T. S. Znachenie infekcij, obuslovlennyh obrazovaniem bioplyonok, v urologicheskoj praktike // EHffektivnaya farmakoterapiya. - 2013. - № 44. - S. 18 27.

12. Perepanova T. S., Volkova E. M. K voprosu patogeneza recidiviruyushchej infekcii nizhnih mochevyvodyashchih putej // Ehksperim. i klin. urologiya. - 2015. - № 3. S. 100-105.

13. Perepanova T. S., Kozlov R. S., Dekhnich A. $V$. i dr. EHmpiricheskij vybor antimikrobnyh preparatov pri neoslozhnennoj infekcii nizhnih mochevyh putej: issledovanie rezistentnosti vozbuditelej DARMIS // Tam zhe. -2012 . - № 2. - S. 78-83.

14. Petuhova I. N. Rol' bioplenok v hronizacii infekcij mochevyh putej // Urologiya segodnya. - 2013. - № 2. - S. 14-15.

15. Prakticheskoe posobie po antiinfekcionnoj himioterapii / Pod red. L. S. Strachunskogo, 
чунского, Ю. Б. Белоусова, С. Н. Козлова. - M., 2007. $-248 \mathrm{c}$.

16. Синякова Л. А., Косова И. В. Антимикробная терапия неосложнённых инфекций мочевых путей // Consilium Medicum. 2014. - № 7. - С. 29-33.

17. Широбоков В. П., Янковский Д. С., Дьмент Г. С. Микробная экология человека. - К.: ООО «Червона Рута-Турс», 2010. $-336 \mathrm{c}$.

18. Anderson G. G., Palermo J. J., Schilling J. D. et al. Intracellular bacterial biofilm-like pods in urinary tract infections // Science. - 2003. - Vol. 301, N 5629. - P. 105-107.

19. Bonkat G. (Co-chair), Pickard R. (Co-chair), Bartoletti R. et al. EAU GUIDELINES ON UROLOGICAL INFECTIONS // 2018 Edition of the Eur. Association of Urology (EAU) Guidelines. Pocket Guidelines. - 2018. - Vol. 415. - P. 257-261. https://ru.scribd.com/ document/376891488.

20. Bonkat G. (Co-chair), Pickard R. (Co-chair), Bartoletti R.et al. Wullt Guidelines Associates: T. Cai, B. Köves, A. Pilatz, B. Pradere, R. Veeratterapillay. Guidelines on Urological infections // Eur. Association of Urology. - 2017. - Vol. 64. - P. - 14-20.

21. Costerton J.W. Cystic fibrosis pathogenesis and the role of biofilms in persistent infection // Trends Microbiol. - 2001. - Vol. 9, N 2. - P. 50-52.

22. Dalhoff $A$. Immunomodulatory activities of fluoroquinolones. // Infection. - 2005. - Vol. 33 (Suppl. 2). - P. 55-70.

23. Dalhoff A., Shalit I. Immunomodulatory effects of quinolones // Lancet Infect Dis. - 2003. Vol. 6, N 3. - P. 359-371.

24. Denstedt J. D., Reid G., Sofer M. Advances in ureteral stent. technology // World J. Urol. 2000. - Vol. 18, N 4. - P. 237-242.

25. Flores-Mireles Ana L., Walker Jennifer N., Caparon Michael, Hultgren Scott J. Urinary tract infections: epidemiology, mechanisms of infection and treatment options // Nature Reviews Microbiology. - 2015. - Vol. 13. - P. 269-284.

26. Grabe M. (Chair), Bartoletti R., Bjerklund Johansen T. E. et al. Guidelines on Urological Infections // Eur. Association of Urology. - 2015. - Vol. 86 - P. 13-26.

27. Joseph A., Parkinson R. Urology and Urinary Tract Infections in Adults // Guideline for the treatment of urinary tract infections in adults // Nottingham Antibiotic Guidelines Committee. 2017. - Vol. 15. - P. 10-13.

28. Lewis K., Spoering A. L., Kaldalu N. et al. Persisters: specialized cells responsible for biofilm tolerance // Biofilms, infection and antimicrobial therapy / Ed. by J. L. Pace, M. Rupp, R. G. Finch. Taylor \& Francis Group, 2005. - P. 241-257.

29. Nickel J. C., Costerton J. W., McLean R. J. et al. Bacterial biofilms: influence on the pathogenesis, diagnosis and treatment of urinary tract infections // J. Antimicrob. Chemother. 1994. - Vol. 33 (Suppl. A). - P. 31-41.

30. Nickel J. C., Olson M., McLean R. J. et al. An ecological study of infected urinary stone genesis in an animal model // Br. J. Urol. - 1987. - Vol. 59, N 1. - P. 21-30.

31. Nickel J. The battle of the bladder: the pathogenesis and treatment of uncomplicated cystitis // Int. Urogynecol. J. - 1990. - N 1. - P. 218-222.

32. Reid G., Habash M., Vachon D. et al. Oral fluoroquinolone therapy results in drug adsorption on ureteral stents and prevention of biofilm formation // Int. J. Antimicrob. Agents. - 2001. Vol. 17, N 4. - P. 317-319.

33. Shigeta M., Komatsuzawa H., Sugai M. et al. Effect of the growth rate of Pseudomonas aeruginosa biofilms on the susceptibility to antimicrobial agents // Chemotherapy. - 1997. Vol. 43, N 2. - P. 137-141.

34. Shigeta M., Tanaka G., Komatsuzawa H. et al. Permeation of antimicrobial agents through Pseudomonas aeruginosa biofilms: a simple method // Chemotherapy. - 1997. - Vol. 43, N 5. P. 340-345.

35. Tenke P., Kovacs B., Jäckel M. et al. The role of biofilm infection in urology // World J. Urol. 2006. - Vol. 24, N 1. - P. 13-20.

36. Wolcott R. D., Ehrlich G. D. Biofilms and Chronic Infections // JAMA: The J. of the Am. Med. Association. - 2008. - Vol. 299. - P. 2682-2684. http://dx.doi.org/10.1001/jama.299.22.2682. 


\section{ЛЕЧЕНИЕ ОБОСТРЕНИЙ ИНФЕКЦИИ МОЧЕВЫВОДЯЩИХ ПУТЕЙ В АМБУЛАТОРНЫХ УСЛОВИЯХ}

\section{Л. Ф. Матюха, Т. А. Титова (Киев)}

Изучена эффективность применения перорального антимикробного препарата Флапрокс и оценена динамика клинико-лабораторных показателей по сравнению с терапией нитрофуранами у больных с обострением хронической инфекции мочевыводящих путей в амбулаторных условиях. Исследованы результаты терапии 40 пациентов с обострением хронического пиелонефрита в возрасте $(39,8 \pm 8,9)$ года. Больные I группы (26 лиц) получали препарат флапрокс по 500 мг 2 раза в сутки в течение 10 дней, II группы (14 лиц) - нитрофуран 0,1 г 4 раза в сутки 10 дней. Регрессирование клинических проявлений инфекции мочевыводящих путей в процессе исследования отмечено в обеих группах. В I группе динамика уменьшения симптомов общей интоксикации и нормализации местных симптомов и воспалительных изменений в крови и моче имела более выраженную тенденцию уже с 5-го дня лечения и сохранялась в течение всего курса терапии. Применение препарата Флапрокс в течение 10 дней позволяет достоверно уменьшить или устранить проявления дизурии, инфицирование мочевых путей (бактериурия), воспалительного процесса (лейкоцитурия) без негативных изменений в биохимическом анализе крови.

Ключевые слова: инфекции мочевыводящих путей; пиелонефрит; флапрокс; кишечная палочка; биоплёнки; лейкоцитурия; бактериурия.

\section{TREATMENT OF OBJECTS OF URINARY TRACT INFECTION IN OUTPATIENT (AMBULATORY CARE) SETTINGS}

\section{L.F. Matyukha, T. A. Tytova (Kyiv, Ukraine)}

\section{Shupik National Medical Academy of Postgraduate Education}

The usage effectiveness of oral antimicrobial drug Flaprox was studied and the dynamics of clinical and laboratory indicators were compared versus with nitrofurans therapy in patients with exacerbation of chronic urinary tract infections on an outpatient basis were evaluated. There were investigated the results of treatment of 40 patients at the age $(39.8 \pm 8.9)$ years with exacerbation of chronic pyelonephritis. Patients of the I group (26 persons) received Flaprox $500 \mathrm{mg}$ twice a day 10 days long, group II (14 persons) - nitrofuran $0.1 \mathrm{~g} 4$ times a day 10 days long. The clinical manifestations regression of urinary tract infection in the research/study process was noted in both groups. In the group I, the dynamics of reduction of symptoms of general intoxication and normalization of local symptoms and inflammatory changes in blood and urine has a more pronounced tendency from 5 days of treatment and persisted throughout the course of therapy. Flaprox useing for 10 days allowed to reliably reduce or eliminate dysuria, infection of the urinary tract (bacteriuria), and inflammatory process (leukocythria) without negative changes in the blood biochemistry analysis.

Key words: urinary tract infections; pyelonephritis; Flaprox; Escherichia coli; biofilms; leukocyturia. 